\title{
Solvency of Insurance Undertakings and Financial Groups
}

\author{
by Norbert Konrath*
}

Having launched the single European Insurance Market mainly through the Third Directives, the European Insurance Legislator now focusses on solvency matters with three major European Commission projects.

1st, a directive on the supplementary supervision of insurance undertakings in an insurance group.

2nd, a directive on the supervision of financial conglomerates, i.e. groups of insurance undertakings with banks or other financial firms.

3rd, a report and maybe amendments to the present European solvency rules for insurance undertakings, i.e. individual insurance firms.

I am going to present to you those three projects from the position of an insurance person who participates actively in negotiations of CEA, the European Insurance Federation, with the competent institutions of the European Union.

However, for a better understanding of the three projects it might be useful to first recall and evaluate shortly the European insurance solvency rules presently in force.

As is well known, one must differentiate between the solvency regulations in respect of non-life insurance and those in respect of life insurance. The legal basis of the non-life solvency system was laid down in Articles 16 to 21 of the First Non-Life Coordination Directive of 24.7.1973, Article 16 (1), amended by Article 24 of the Third Non-Life Coordination Directive of 18.6.1992. These regulations, which are being incorporated into the national law of the member states of the European Union, apply as to the entire property and casualty insurance business with special provisions for hail and frost insurance and health insurance if practised on a similar technical basis to life insurance. The concept underlying the regulations is that insurance undertakings should have a solvency margin of free capital resources determined by their volume of business in addition to adequate technical insurance provisions.

The solvency margin - in truth not a margin but a required minimum amount of own funds - is determined by the higher of two "indices": the premium index and the claims index. The premium index is $18 \%$ of the gross written premiums in the year of account up to 10 million Units of Account (ECUs) plus $16 \%$ of premiums in excess thereof. This total

\footnotetext{
* Director, Allianz Versicherungs AG, Munich.
} 
is reduced by the percentage that reinsurers contributed to the claims cost in the year of account up to a maximum of $50 \%$. The claims index is $26 \%$ of the first 7 million Units of Account - and $23 \%$ of the remainder - of the average of the gross claims of the last three financial years or seven years in the case of natural catastrophes, again reduced for reinsurance similarly to the premium index. For health insurance practised on a similar basis to life assurance both indexed results are reduced by one third. As stated, the higher of the amounts calculated on the two indices is the relevant solvency margin.

A property and casualty insurance undertaking must have "free of all foreseeable liabilities, less any intangible items" of the amount of this solvency requirement. The term "assets" is to be interpreted, not in the sense of the accountancy conventions, but in the sense of appropriate free resources available to meet losses. Article 16 (1) of the First Nonlife Coordination Directive as replaced by Article 24 of the Third Non-life Coordination Directive sets out, in an illustrative "catalogue", the following abbreviated items:

- The paid up share capital or, in the case of a mutual insurance undertaking, the effective initial fund,

- one-half of the unpaid share capital or initial fund once the paid up part amounts to $25 \%$ of that share capital or fund,

- reserves (statutory reserves and free reserves) not corresponding to underwriting liabilities,

- any profits brought forward,

- in the case of a mutual-type association, one-half of the allowable supplementary contributions-type association in the financial year subject to a limit of $50 \%$ of the margin.

- on request and with the agreement of the home country supervisory authority responsible, any hidden reserves arising out of undervaluation of assets and finally, subject to specified conditions and limitations and in accordance with member state options, a further three items namely,

- subordinated loan capital,

- participating notes capital,

- preference share capital.

Most of these items are shown in the balance sheet - in the technical jargon "explicit". Supplementary contributions and hidden reserves (the latter at any rate for the present) are not shown in the balance sheet and are therefore termed "implicit". Intangible assets such as amortised expenditure for the establishment or expansion of the concern and goodwill are to be deducted from the total - explicit and implicit - assets.

The basis in European law governing the solvency system for life assurance is contained in Articles 16 to 25 of the First Life Coordination Directive of 5.3.1979, in particular Article 18 (2), (1) (catalogue of free reserves) as amended by Article 25 of the Third Life Coordination Directive of 10.11.1992.

The solvency requirements, laid down in the directive and incorporated in the national law of the member states of the EU, apply to all life assurance undertakings, in particular those conducting whole life or endowment assurance or annuities, with special provisions in relation to term life insurance and index-linked assurances to which I only very briefly refer. 
The basic solvency concept described for property and casualty insurance applies also to life assurance, namely that every insurance undertaking should have a defined solvency margin of free capital resources in addition to adequate technical insurance provisions, and in this case particularly mathematical policy "reserves".

The solvency requirement for life assurance and annuity business is however determined not by premiums and claims payments but by actuarial provisions and capital at risk, in view of the nature of this business with its extensive transactions of saving and dissaving.

The minimum solvency margin is here the total - and not as in property and casualty insurance the higher - of two amounts

$4 \%$ of the gross mathematical "reserves" for the whole insurance business taking account of reinsurance up to $15 \%$ and

$3 \%$ of the gross "capital at risk" for the whole insurance business taking account of reinsurance up to $50 \%$.

The mathematical "reserves", in particular the policy provisions are the reference value for the investment risk and the "capital at risk" is the reference value for the mortality risk being equal to the difference between the total sums insured and the accumulated premium "reserves". In this connection it is significant that the solvency requirement for index-linked insurances, where the policyholder bears the investment risk, is reduced to one-quarter, i.e. $1 \%$ of the mathematical "reserves" but not in respect of capital at risk where the $3 \%$ requirement remains.

The life assurance undertaking must set against the solvency requirement thus calculated its permissible free assets in order to demonstrate their adequacy. In this respect the same catalogue applies as in the case of property and casualty insurance. In addition the following two items are recognised as free reserves for the purposes of the solvency regulations in the case of life assurance undertakings:

- Profit reserves in so far as they may be used to cover losses and where they have not already been allocated to policyholders, i.e. the freely available part of these reserves and

- subject to application to the home country supervisory authority responsible; one-half of the future profits. This would be calculated as the product of the estimated annual surplus and the average period left to run on the policies.

This review demonstrates that, in life assurance, implicit values, that is items that are not directly taken from the balance sheet, play a more important role than in property and casualty insurance.

This comparison of the fundamentals of the solvency regulations for property and casualty insurance and life assurance should be the most arid part of this report; even so I should excuse myself to the specialists and to the seekers after detail for the repetition and the superficiality respectively.

The current European solvency requirements which I have described, serve a double purpose. As I have pointed out they should ensure that insurance undertakings have available, in addition to adequate provisions (and their coverage by sound investments) to meet their insurance contractual liabilities, additional guarantee funds. They should also provide the insurance supervisory authority with an instrument for control and intervention. 
The latter means that insurance undertakings must report on their solvency annually, as a rule on the basis of their annual accounts and that, if this is inadequate, the supervisory authority can resort to a graded range of measures. If the free assets fall below the solvency margin a solvency plan must be submitted for approval; if they do not even reach the level of the Guarantee Fund, the minimum guarantee fund being determined as one-third of the solvency margin and fixed amounts according to certain classes of business, the supervisory authority requires a short-term financing plan. In addition, at this point, the authority can limit the undertaking's freedom to dispose of its assets and, as a last resort, withdraw the authorization to conduct business. It should be noted that the supervisory authority does not replace the insolvency jurisdiction; it can, as a rule, only apply for liquidation. Inadequate solvency as described here does not so far mean insolvency but can lead to it. We are therefore concerned with an "early warning system", although the use of the word "early" is arguable.

It is an interesting question, which risks should be covered by the minimum solvency prescribed? In particular, the premiuns and claims basis for the calculation of the solvency requirement in property and casualty insurance has led to the conclusion in scientific discussion that only the insurance technical risk is intended, that is in particular the event of indequate insurance technical provisions. However the history of the European solvency regulations for all branches of insurance and the construction of the solvency requirement in life assurance demonstrate that the investment risk also was certainly brought into consideration. Here we are concerned with an overall system determined for the sake of simplicity on the basis of insurance technical amounts. In the final section of my remarks, I will briefly introduce a completely different concept under the keyword "Risk Based Capital".

The adequacy of the assets solvency requirements has also been the subject of fierce argument between the experts, particularly in the early years following the introduction of the European regulations. I recall that about 15 years ago a Belgian actuary reckoned that the required solvency margin in property and casualty insurance should amount to only $4 \%$ (instead of 18/16) and simultaneously a certainly no less qualified Dutch actuarial colleague, who took into account the investment risk, arrived at $40 \%$ (in words forty per cent!) of the gross premium income. This example should not lessen our high respect for the actuarial profession.

Again, concerning the adequacy of the solvency requirements, the European Commission, which has the task of reviewing the practical effects of the requirements of the directives periodically, has so far not been able to establish either a general overrequirement or a general underrequirement in terms of exposure to danger notwithstanding the fulfilment of the insurance undertakings' solvency requirements. One will observe whether the current solvency requirements can still be achieved and whether they will be adequate in the light of the politically desired and expected increased competition in the European internal insurance market with its greater freedom in underwriting and investment. If increased competition for the benefit of the consumer leads to reduced profit margins, a dilemma will arise: At any rate in theory, greater risks and lower profit margins require larger guarantee funds. In practice, these are then harder to establish, whether by internal or external financing.

Before I discuss the future development further, in order to illustrate the connection, I would like briefly to set out some business strategies aimed at attaining the required solvency as well as some of the open questions on the present European solvency system for insurance undertakings to which answers are sought. 
Solvency strategies are aimed at the continuous fulfilment of the solvency requirement. This is demanded by the spirit of allegiance to the law but also by recognition of the necessity of adequate financing, concern for one's market image, and endavours to avoid difficulties with the supervisory authority. The maintenance of adequate solvency in the face of the expansion of business that we, in the European market, have fortunately enjoyed for many years is, however, not a simple matter. For example, consider the case of a property and casualty insurer, who reinsures $25 \%$ of his portfolio, who has a favourable claims ratio under $70 \%$ and whose solvency requirement calculated on the premium basis is just met. If his gross premium income increases by $10 \%$ (for ease of calculation), $12 \%$ of the additional premium income $(16 \%$ minus the $25 \%$ reinsurers' share $=12 \%)$ will require to be covered by free assets which is equivalent to $1.1 \%$ of the total gross premium income. As practitioners in this branch you will know that, even in our reputedly so highly protected continental European market, far from all insurers (and certainly not in all years) achieve such profit margins, which depending on the country concerned may, pre-tax, equal double or treble that amount.

Basically, there are three conceivable strategies for the maintenance of solvency: abandonment of expansion, increase in capital and reinsurance.

The first is a non-strategy. Abandonment of expansion leads, sooner or later, to withdrawal from the market, apart from the fact that increasing claims in property and casualty insurance will inevitably involve an increased solvency requirement on the claims basis of calculation.

The second strategy, increase of capital whether by internal. or external financing, depends on successful results from the insurance undertaking. The difficulties of raising capital, particularly for mutual insurance societies who for many years have been dependent on self-financing, have however been considerably ameliorated in recent years by the recognition at the European level of participating notes capital as own funds subject to conditions as now embodied in the Third Coordination Directive.

The third strategy, reinsurance, is feasible but, in property and casualty insurance for example, reaches its limit at the $50 \%$ claims mark as explained above, not do mention the fact that reinsurance costs money.

One might think of a fourth "strategy": Creative accounting. This sounds funny, but the background is serious. If solvency requirements are to heavy a burden, there will be an increasing temptation to shift necessary amounts from technical provisions to reserves even at the price of higher taxes. Fortunately enough the economic situation of the European insurance industry helped to avoid - so far - a spread of this phenomena and its unavoidable prudential consequences.

In particular, if undertakings reach the limits of these strategies, the exhaustion of the room for manœuvre in the European solvency regulations as incorporated in national laws will become a matter of interest. Here we come to the problem area.

Firstly, there are the possibilities to apply for the recognition of hidden reserves or future life assurance profits. Although the European supervisory authorities have long since agreed a unified practice in relation to the recognition of hidden reserves, they have nevertheless made this recognition subject to an "if". The recognition of hidden reserves (on the assets side) simply accords equal treatment to those undertakings which also evaluate their capital investments for the solvency calculation on the purchase cost price basis and to those who base them on current market values. 
Apart from the question of non-uniformity in the practice of recognition, questions of interpretation arise such as: Can an establishment fund be recognised as free assets? Can the "Equalization reserve" be recognised as equivalent to a reserve for the solvency calculation in those countries where it is considered to be an actual provision? Here again the practice in the member states of the European Union does not seem to be at all uniform.

Finally, some member states of the European Union have introduced at national level measures stricter than the European solvency regulations. Thus in Great Britain, amongst others, professional reinsurers are subject to the full solvency requirements even though such undertakings are not encompassed by the solvency regulations of the European Coordination Directives. In this instance, owing to lack of regulations, member states have freedom. On the other hand the practice of some EU insurance supervisory authorities whereby a participation by an insurance undertaking in another insurance undertaking is deducted in the determination of the solvency in the same way as intangibles seems to be questionable in law. This applies, albeit with variations, in Denmark, Germany, Great Britain, the Netherlands and Spain.

With this illustration of these problems, which time does not permit me to enlarge on, I will leave the subject of legislation and supervisory practice and turn to consider the development trends in the European solvency system for insurance undertakings. I propose to discuss three issues in the timing order of the anticipated changes; the solvency of insurance groups, the solvency of financial conglomerates and consideration of a reform of the solvency requirements for individual undertakings.

\section{The proposals for special solvency regulations for insurance groups}

This issue is actually promoted under a much more neutral title, namely "Supplementary supervision of insurance undertakings in an insurance group", as the European Commission's proposal for a directive at present under discussion is entitled. ${ }^{1}$

What is the issue? It should be remembered that the Third Coordination Directives, aimed at realising the European internal market for insurance, envisage a strengthening of competition in the interests of consumer, replacing the continental European material insurance supervision of policy conditions and tariffs in favour of a system of stronger financial supervision by the home country supervisory authority.

The European supervisory authorities are considering how they can best adapt to their changed responsibilities. The Third Directives together with the Insurance Accounts Directive of 19.12.1991 provide three principal instruments in relation to solvency: control of the financial backing and fitness of the proprietors; harmonisation, if not uniformity, of the annual financial statements on which the solvency calculation is, as a rule, based and thirdly the possibility to require an insurance undertaking to furnish information for the evaluation of its financial position at more frequent intervals, e.g. quarterly. These instruments can well be integrated into the present European system of supervision of insurance undertakings which is, as explained, designed for single firms, and also where the contractual obligations to policyholders are not underwritten by a group but by an individual contracting insurance undertaking. Presently, this is referred to as "solo" supervision.

${ }^{1}$ Brussels, 04.10.95, COM (95) 406 final, 95/0245 (CAD). 
This "solo" supervision has come under increasing criticism as a result of some spectacular insolvencies, mainly in banking groups and outside the European continent - for example the case of BCCI, Bank of Credit and Commerce International. The argument is that the consideration of the individual undertaking is no longer sufficient. Supervision of groups - which are increasingly international - or least consideration of the group associations of the individual undertakings being supervised is necessary.

In the insurance sector this argumentation has led, under initial pressure from the banks, to the above mentioned directive proposal on the supplementary supervision of insurance undertakings in an insurance group. In addition to requirements for the provision of information regarding group relationships (to a large extent already including in the Third Coordination Directives in the insurance sector and in the BCCI-Directive), this proposed directive envisages a strengthening of the supervision over intra-group transactions, and above all solvency requirements aimed at so-called "double gearing". In the light of the subject matter of this paper, I will restrict myself to consideration of this last aspect.

"Double gearing" is simply the ability of an undertaking to expand its business activity without additional capital by acquiring a participation in a subsidiary company instead of investing otherwise. The so-called multiple appropriation of capital is a financial advantage that all groups enjoy over single undertakings in every sector of the economy. As, however, insurance undertakings - and also banks - are subject, at any rate within the EU, to solvency regulations which lay down a minimum relationship between free assets and volume of business, the question arises whether supervised group undertakings should be deprived of this financing advantage in order to put them on a par with stand alone undertakings in this respect. In theoretical discussions within the insurance industry, this question is "old stuff", if you will pardon the expression, and answers have been found in the supervisory practice of a number of Member States as has been mentioned above.

The search is now for a European harmonisation of measures against "double gearing" and this is being driven by the fear that the participation of one insurance undertaking in another insurance undertaking involves the risk of a reduction in solvency, i.e. an increase in the probability of ruin. This fear is rationalised primarily on the basis of three linked dangers to which the parent undertaking is said to be exposed: The danger of the loss of the value of the participation, the danger of an accumulation of risk and the danger associated with responsibility for the liabilities of the associated undertaking itself.

The possibility of loss of value of the participation on its own would only justify supervisory preventive measures if a participation in another financial institution would be riskier, (i.e. the probability of loss greater), than a participation in a different branch of industry. However this is not the case because of the statutory supervision of financial institutions such as insurance undertakings. In addition, this problem can be addressed by the simple measure of the value to be placed on the participation in the balance sheet.

However the fear remains that the parent company may suffer from a particular loss arising from the same business as may have given rise to a loss of value of the participation. This accumulation of risk (risk of contagion) arises in banking groups where the parent and subsidiary firms often participate in the same loan (so-called "credit pyramid") and as rule will both be affected by an economic recession. In the case of "pure" insurance groups (participations by insurance undertakings in other insurance undertakings) an accumulation of risk only arises in the case of identity of business which in this sector is exceptional as insurance groups are typically groupings of specialised undertakings (i.e. life, property and 
casualty, sickness). This may be different in the case of "multinationals" but, because insurance cycles at national level still differ from country to country, in this respect the nonconcurrent risk situation remains unaffected thereby. Even if internal rcinsurance is undertakcn within a group, the risk situation of the eeding direct insurer differs from that of the accepting reinsurer who, in current reinsurance practice, effects, his own retrocessions and is concerned to balance his portfolio. The accumulation of investment risk is also less than that of banks becaluse of the cash-flow provided by the insurance premiums and because of the investment regulations aimed at security and profitability as well as diversification and spreading of investments.

The third risk feared to arise from a participation of one financial institution in another is the liability of the parent for losses of the subsidiary firm. In the absence of harmonisation of the relevant company law in the EU, this is detcrmined by the regulations of the individual member states uncier which, as a rule, there is not even a legal liability for the firm's losses in the case of a majority holding. Uniform European thresholds for participations ale, at this stage, not justifiable for supcrvisory measures.

The European Commission and the insurance supervisory aluthorities of the EU member staies seem to be disinclined to accept the foregoing an alysis of the risks. They are much more concerned to avoid the financial effect of "double gearing" by financial supervisory techniques and thus to place grouped undertakings and independent undertakings in the insurance sector on the same footing. In spite of the different circumstances it is the banks that are the criterion.

The Dircetive proposal"on the supplementary supervision of insurance undertakings in an insurance group" envisages measures against the effects of double gearing, which - starting from an insurance participation of $20 \%$ - take into consideration not only supervisory (direct) insurers but also reinsurance undertakings and insurance holding companies. As a first step, a so-called "adjusted solvency" has to be calculated (it is left open by whom), whereby a distinction is made between insurance undertakings (Art. 9, Annex I) on the one side and insurance holding companies (Art. 10, Annex II) on the other. An overview of the two sets of calculation methods is given in the following two tables: 


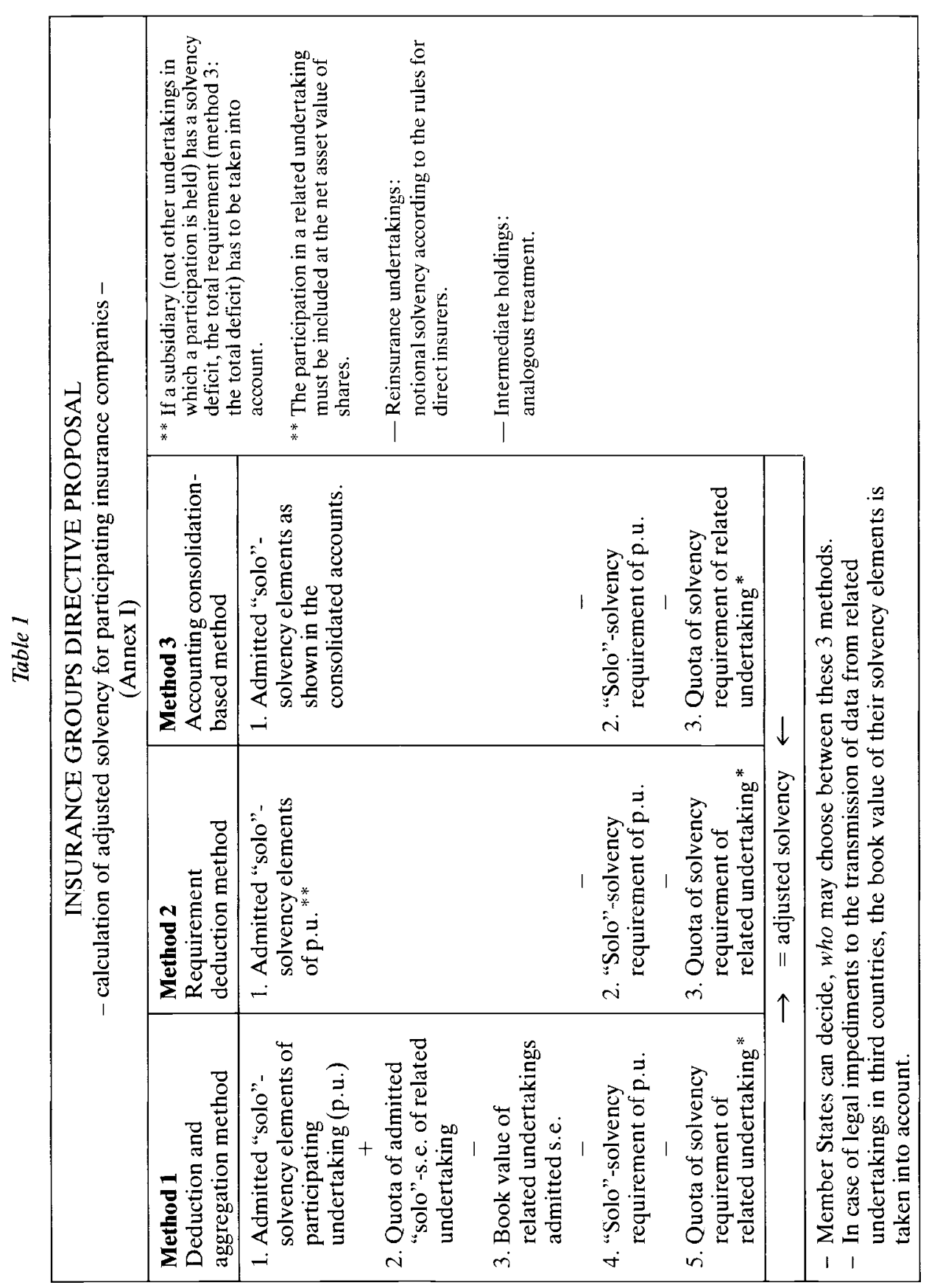


Table 2

\begin{tabular}{|l|}
\hline \multicolumn{2}{|c|}{$\begin{array}{l}\text { INSURANCE GROUPS DIRECTIVE PROPOSAL } \\
\text { - calculation of adjusted solvency for insurance holding companies - } \\
\text { (Annex II) }\end{array}$} \\
\begin{tabular}{|l|l|}
\hline $\begin{array}{l}\text { Method 1 } \\
\text { Solvency warning test }\end{array}$ & $\begin{array}{l}\text { Method 2 } \\
\text { Accounting consolidation test }\end{array}$ \\
\hline $\begin{array}{l}\text { 1. Capital of insurance holding } \\
\text { company }\end{array}$ & $\begin{array}{l}\text { 1. Consolidated capital of insurance } \\
\text { holding company (Annex I method 3) }\end{array}$ \\
$\begin{array}{l}\text { 2. Sum of solvency requirements of } \\
\text { related insurance undertakings } \\
\text { and notional solvency of related } \\
\text { reinsurance undertakings. }\end{array}$ & $\begin{array}{l}\text { 2. Sum of solvency requirements of } \\
\text { related insurance undertakings } \\
\text { and notional solvency of related } \\
\text { reinsurance undertakings. }\end{array}$ \\
must be $>$ or $=0$ & must be $>$ or $=0$ \\
\hline
\end{tabular} \\
\hline
\end{tabular}

If the adjusted solvency calculated according to these methods is insufficient, supervisory authorities have to take "appropriate measures" at the level of the supervised direct insurer in question. Although the directive is proposed with the argument of avoiding distortions of competition, the harmonization of these measures is not envisaged.

If you have followed the description in Tables 1 and 2 attentively you certainly have grasped that these measures against the effects of double-gearing require in substance a double financing of participations as compared with the situation where double-gearing is allowed. It was calculated that with a worst case interpretation of the Directive Proposal the European insurance industry would need a two digit billion US-Dollar-amount of new capital. This amount would be big enough to have an influence on the allocation of scarce capital and on the price of insurance.

The insurers represented by CEA do not, however, reject the directive proposal, maybe because they realistically see that measures against double-gearing are politically inevitable. Thus they have asked the European Commission in principle and in detail to restrict the directive to what is necessary and bearable. The three essential points of CEA-demands are: 1st, to restrict the scope of the directive to undertakings figuring in the consolidated accounts rather than the treshhold of a participation of $20 \%$ envisaged by the European Commission. The argument is in substance, that measures seem justified at the most in cases of dominant influence (certified by public accountants);

2nd, exclusion of holding and reinsurance undertakings. The argument is that these undertakings are not submitted to European solvency rules.

3rd, all items taken into account in solvency for solo-supervision should also be admitted for the additional solo-supervision of insurance undertakings in a group. This refers to the 
exclusion of implicit solvency elements of life insurers in the Directive Proposal. The argument is, that these elements do not derive from intragroup transactions but are earned from outside the group and can be used to cover every type of loss.

It seems that only the insurers have the impression that the Directive Porposal is guided by the idea of comprehensive and comfortable insurance supervision rather than by the risk situation. A couple of months ago a high ranking Civil Servant of the French insurance supervision doubted publicly, whether measures against double-gearing touch the real problems of insurance insolvency. l'm inclined to underline this.

\section{The proposals for special solency regulations for financial conglomerates}

To this item of my report, my comments will be relatively short, since this project is not as advanced as the future directive on insurance groups.

The international discussion on the supervision of financial conglomerates is reflected in a report by the Tripartite Group of bank, securities and insurance regulaters released to the international press on July 24, 1995. This group was headed by Mr. de Swaan of the Dutch Central Bank and sponsored by the Basle Committee of Banking Supervision, the International Organization of Securities' Commissions - IOSCO - and the International Association of Insurance Supervisors. This 115 pages report will be followed up by a restricted tripartite group, again under the chairmanship of Mr. de Swaan, and with the task to develop rules for the practical cooperation of supervisory authorities.

On the part of the European Commission there exists a confidential draft report on prudential supervision of financial conglomerates worked out by a mixed technical insurance and bank expert group. The final version of this report might be the basis of a European directive. In both papers the measures suggested are very much the same as those comprised in the Directive Proposal for insurance groups. Thus I will not go into any details of these papers. The main difference between the insurance group Directive Proposal and these papers is that they extend to financial conglomerates which are defined in the words of the Tripartite Group report as "any group of companies under common control whose exclusive or predominant activities consist of providing significant services in at least two different financial sectors (banking, securities, insurance)."

The discussion on financial conglomerates was launched by the banking sector. For many years, banks were already submitted to certain ratios between credit volume and their own funds. These relations were circumvented in practice through the establishment of subsidiaries, not at least in tax heavens. So called credit pyramids arose which led already in 1983 and - after the adoption of the seventh Directive on group accounts - to a 1992 European directive on prudential supervision of banks on a consolidated basis. The exact methods are however left to the national supervisors. Thus, for example in Germany consolidated supervision only starts with participations of $40 \%$ and more.

In substance consolidated supervision in the banking sector is very much the same as homeland control in insurance, extended, however, to subsidiaries and with the consolidated accounts as a basis. In addition, it is interesting that solvency surpluses and deficits might be compensated within the group under certain circumstances.

As I already said, the risk situation of banking concerns and insurance groups differs, because the undertakings of the latter do share much less the same business and are less 
sensitive to business cycles and public confidence. The contagion between banks and insurance undertakings in a financial conglomerate does not seem to be a considerable risk as long as the two work with separate licences.

We should also keep in mind that the supervision of banks and insurance undertakings have different objectives. For the banks it is the functioning of the monetary system, whereas for insurance undertakings it is the protection of policy holders and third parties. As I already pointed out, these are no clients or creditors of an insurance group but of individual insurance undertakings.

Apart from these considerations the extension of so called consolidated supervision from banks to insurance groups is often advocated with the argument of level playing fields in competition. We should not overestimate this argument. Competition between banks and insurance undertakings is mostly restricted to some life insurance products and to credit insurance. Even this part of competition is increasingly excluded by arrangements of cooperation between banks and insurance undertakings and especially between the member companies of financial conglomerates.

In the discussion on the prudential supervision of financial conglomerates the banks seem to pursue two objectives. The first one is the use of insurance undertakings' solvency surpluses for the conglomerates banking business. If this would be ruled out, the topic would loose its business charm for the banks. If this would be conceded, solvency of the conglomerate would not be safer, but less secure, especially when insurance specific or implicit solvency elements are taken into account.

The second objective is - at least on a European level - more long term. It is the submission of financial conglomerates to a single supervision which by all experience would be that of the banks. If you think that this is exaggerated, I recommend to read the study on financial conglomerates and their supervision in the monthly report of the German Bundesbank of April 1994 which is an excellent summary of the discussion mainly with a banking point of view.

It is difficult to forecast at what time the European Union will come out with a directive on the prudential supervision of financial conglomerates. But you can take one thing for sure: As I already told you, the measures against double-gearing envisaged for insurance groups will create an enormous need for additional capital. An extension to financial conglomerates would create a considerable additional need of own funds for members of such conglomerates.

\section{Preliminary considerations for the review of the European solvency regulations for insurance undertakings}

I come now to my last heading. Preliminary considerations regarding such a reform arise, within the EU, from Article 25 of the Non-life Coordination Directive and Article 26 of the Life Coordination Directive which provide that the European Commission must submit a report to the insurance committee on the need for a subsequent harmonisation of the solvency margin not later than three years after the prescribed date for implementation of these Directives, i.e. up to 30.6.1997. A questionnaire has been sent on behalf of the EU to the insurance supervisory authorities of the EU member states. The answers of the national commissioners are now available and the working group now investigates in risk exposure 
and in the reasons for the cases of insurance failures which happened in Europe. At the moment, it seems that the degree of satisfaction with the present European solvency rules is rather high and that eventual amendments to them could be relatively modest.

But this may not be the only root cause. Some insurance supervisory authorities take the view that the Insurance Accounts Directive, which applies from 1.1.1995, creates an opportunity for a discussion on solvency, particularly as it involves a greater provisioning requirement in some countries. I do not find this argument convincing as increased financial demands for additional provisions can be accommodated within the existing system and certainly no reduction of the solvency requirements is planned. More serious is the question whether greater competition and freedom of investment increase the risks of the insurance undertakings to such an extent that stronger precautions are necessary. In this regard, the supervisory authority should concentrate first and foremost on the adequacy of the insurance technical provisions and the security of the investments. Over and above this, the banks could be interested in a greater convergence of the solvency regulations of the insurance undertakings towards the rules prevailing in the banking sector. This could -depending on the circumstances - facilitate setting off the solvency surpluses of insurance undertakings in financial conglomerate as well as the unification of the supervision of such groups. Whether the insurers would welcome this is another question.

In addition I mention a revived discussion amongst actuaries, especially nordic ones, who try to find out a more risk adapted solvency system for insurance undertakings. The problem of these rather theoretical deliberations seems to be the data for the parameters necessary for such a system.

Of more short-run time relevance might be the discussion going on in OECD. The Insurance Committee of this organization is working on a report and recommendations on the solvency of insurance undertakings to be published this year. The insurance industry is excluded from this work and the Americans - members of OECD - are included.

The insurance supervision in the USA, organised on a state basis, which in the past has influenced the European discussion with early warning systems and group solvency considerations but nevertheless could not prevent insolvencies, now seems to have discovered the ultimate solvency formula, namely the "Risk Based Capital" system - in short RBC system (incidentally related to a large extent to individual firms).

The starting point is the concept that insurance undertakings are exposed to four categories of risks. In Life Assurance these are:

- The "Asset Risk": This is the risk attached to the assets and, in particular, the investments.

- The "Insurance Risk and Obligations": This is the risk of variable insurance experience as regards the insurer's liabilities.

- The "Interest Rate Risk": This is the interest rate risk in the insurance business.

- The "Business Risk": These are all other risks of the business.

For Non-Life Insurance the risk categories are:

- The "Asset Risk": This is defined as the risk of variations in interest and market value of the assets.

- The "Credit Risk": This is the risk of default on claims against reinsurers, policyholders and other debtors. 
- The "Underwriting Risk": This is the risk of underestimation of liabilities in respect of existing insurance business and inadequate premiums for insurance business in the next underwriting year.

- The "Off Balance Sheet Risk": This is the risk attached to perils that do not appear on the balance sheet such as excessive premium growth and other obligations etc.

Percentage adjustments are determined for the relevant balance sheet items for life insurance and foe property and casualty insurance in the light of these risks. These percentage factors are not uniform but are adjusted e.g. for the ten largest investments, or if the property and casualty business is concentrated in particular classes and for group-related items. Thus a control function is simultaneously built in. Finally, an overall percentage of the risk loadings is determined which the insurer's capital must comply with. If the free assets are below the solvency requirement as thus calculated, the supervisory authority can or must intervene with measures determined by the percentage of deviation. Interestingly, the same applies if the requirements are substantially exceeded. In this event the supervisory authority can demand the submission of a business plan.

I can not here expound on the details of the US-American RBC system but I submit the following remarks for your consideration: At first sight the system has business attractions. However, the percentages leading to the solvency requirement leave considerable scope for judgement. When the association of American supervisory authorities, NAIC, made the first estimates in respect of the property and casualty insurers, the result was a mathematical ruin for almost the whole of the US insurance industry and one spoke of the "Doomsday effect". The percentages were then manipulated until eventually they seemed to be acceptable in practice. Further, one should bear in mind that life insurers have been controlled under the new system for the first time on the basis of the figures for 1993. Property and casualty insurers had to furnish the necessary data for the first time for the business year 1994. However, "Risk Based Capital" will not become the supervisory authorities' standard and thus the basis of the supervision requirements for this insurance sector until 1.1.1997. We are not therefore concerned here with a system that has already proved itself in supervisory practice. Incidentally, here again the predilection of the American authorities for "red tape" is in evidence. The forms to be completed by the undertakings together with the instructions for completion comprise 47 pages for life insurers and for property and casualty insurers 58 pages plus 17 pages of appendix. Our European overall system is in this respect somewhat simpler.

To end this commentary, the following short story may illustrate possible consequences of the current discussion on insurance solvency: I recently expressed to a supervisory official of a non-German member state of the EU the concern that additional solvency requirements for insurance undertakings resulting from their membership of an insurance group, membership of a financial conglomerate or even from the reform of individual solvency along the lines of "Risk Based Capital" could lead to difficulties for the European insurance industry in the event of an increase in competition. The unadorned and cool answer was that there were just too many insurers in Europe and a cleansing of the market was necessary. One should consider whether a possibly necessary rationalisation of the internal insurance market for which the European insurance directives strive must really be achieved through excessive statutory solvency requirements or whether it is not better left to market forces, i.e. competition. 